\title{
Challenges experienced by immigrant entrepreneurs in a developing non-Western country: Malaysia
}

\author{
Hamizah Abd Hamid
}

\section{A B S T R A C T}

Objective: The objective of the article is to explore the challenges experienced by immigrant entrepreneurs in a developing non-Western immigrant-receiving country.

\begin{abstract}
Research Design \& Methods: Through a qualitative approach, this study examined the experiences of immigrant entrepreneurs from Indonesia, Pakistan, and South Korea in one host country, Malaysia.
\end{abstract}

Findings: The findings suggest that the formal aspects of host country institutions are mainly instrumental in the commencement stages of immigrant entrepreneurs' ventures and the informal aspects of institutions are predominantly influential in the developmental stages of immigrant entrepreneurs' ventures. Specifically, the findings indicate that the challenges experienced by immigrant entrepreneurs in the host country mainly stem from (1) governing institutions, (2) resource-providing institutions, (3) local society and (4) competition in the host country.

Implications \& Recommendations: Through the model, this study provides a layer of knowledge in immigrant entrepreneurship activities conducted in developing nonWestern countries, which is a fertile area of interest in immigrant entrepreneurship. Practice-wise, this study provides useful evidence in assisting immigrant entrepreneurs and host country's policymakers who deal with trade and migration to create a more sustainable landscape for immigrants to conduct entrepreneurship activities.

Contribution \& Value Added: This research contributes to the immigrant entrepreneurship literature by further gauging the way home-host country dynamics influence the experiences of immigrant entrepreneurs in conducting their ventures in a foreign country.

\begin{tabular}{ll}
\hline Article type: & research article \\
Keywords: & immigrant entrepreneurs; Malaysia; entrepreneurship \\
JEL codes: & J15, F22, L26
\end{tabular}

Received: 23 August 2019 Revised: 29 May 2020 Accepted: 14 June 2020

\section{Suggested citation:}

Hamid, H.A. (2020). Challenges experienced by immigrant entrepreneurs in a developing non-Western country: Malaysia. Entrepreneurial Business and Economics Review, 8(3), 7-25. https://doi.org/10.15678/EBER.2020.080301 


\section{INTRODUCTION}

As an academic discourse, immigrant entrepreneurship has mainly focused on developed Western countries, leaving a gap in understanding the phenomenon in countries beyond the conventional spectrum (Aliaga-Isla \& Rialp, 2013). This study addresses this gap by investigating the way immigrant entrepreneurs (IEs) deal with the environment of a developing non-Western immigrant-receiving country through a qualitative approach. The outcome of this research is a nuanced view of how host country institutional environment influences entrepreneurial activities conducted by immigrants.

Institutions are a result of formal and informal rules based on regulatory structures, governmental agencies, laws, courts, professions, scripts, and other societal and cultural practices (DiMaggio, 1991). The political-institutional and sociocultural environments influence entrepreneurial attitudes and motives, the resources that can be mobilised, and the constraints on and opportunities for starting and running a business (Greenman, 2013; Martinelli, 2004), which are more salient for individuals such as IEs who operate business activities across borders, as they are considered as 'outsiders' in a host country. This aspect has been addressed in the immigrant entrepreneurship discourse; whereby immigrants' limited knowledge of the host country, in interaction with the host country's sociocultural context pushes them into entrepreneurship in marginal sectors (Aliaga-Isla \& Rialp, 2013; Kloosterman, van der Leun, \& Rath, 1999). However, as there is much to explore with regards to IEs' experiences in complex environments of developing and non-Western nations, this research focuses on the question: What are the challenges experienced by IEs in conducting their ventures in a developing non-Western host country?

While the developed Western world consistently hosts a large pool of immigrants, immigration to such countries slowly declines due to many immigration policy reforms; while immigration to developing non-Western nations gradually rises (United Nations, 2019). Developing and non-Western countries such as Malaysia provide a useful background in understanding institutions and immigrant entrepreneurship activities due to its nascent experience in dealing with foreign entrepreneurs (Abd Hamid, O'Kane, \& Everett, 2019)and the role of culture and traditions shaping its environment (Barkema, Chen, George, Luo, \& Tsui, 2015). As an implication, international business decisionmakers navigate the complexity of relationship-based processes and the host nation's focus on development (Barkema et al., 2015; Sharma, Luk, Cardinali, \& Ogasavara, 2018). Here, it is timely and worthwhile to understand the way IEs deal with such contexts in their entrepreneurial endeavours.

This research focuses on IEs from Indonesia, Pakistan, and South Korea (henseforth: Korea) in a single host country: Malaysia. Malaysia offers this study a background of a regulated entrepreneurial environment and culturally-infused cognitive and normative environment (Carney \& Andriesse, 2014), shaping the complexity for foreigners who conduct businesses in the host country. Such home countries provide this study with a richer account of immigrant entrepreneurship experiences, through the characteristics of their home countries contingent to the host country, in light of the call for more knowledge on home-host country dynamics in influencing immigrant entrepreneurship activities (Dheer, 2018). The utilisation of qualitative approach through these home and host countries will assist scholars discussing entrepreneurship activities conducted by immigrants through (1) 
lifting the over-reliance on non-Western contexts in discussing such issues and (2) examining the phenomenon from various home country perspectives.

This paper begins with a discussion of the concepts underlying the study. Then, the research design and methods used are outlined. Next, this paper presents its findings, followed by the conclusion, which addresses the theoretical and practical implications of the study.

\section{LITERATURE REVIEW}

According to North (1990), "Institutions are the rules of the game in a society or, more formally, are the humanly devised constraints that shape human interaction" (p. 3). This study defines IEs as immigrants engaged in entrepreneurial activities in the host country (Chaganti, Watts, Chaganti, \& Zimmerman-Treichel, 2008). Institutions include notions of the legal environment, economic incentives, culture, tradition, and history, which shape social interaction through providing constraints and enablers for activities and decisionmaking (Greenman, 2013). At the heart of the institutional perspective in entrepreneurship are the assumptions that material infrastructure, rules, underlying values, and expectations in countries shape entrepreneurial activities (Bruton, Ahlstrom, \& Li, 2010; Lim, Oh, \& De Clercq, 2016).The institutional logics outlines this study on the basis of decision-making in a specific context, which is shaped by the institutional environment of the setting.

\section{The Environment of the Host Country and Immigrant Entrepreneurship}

The formal aspects of institutions refer to the formally codified, enacted, and enforced structure of laws in a community, society, or nation (North, 1990, 2005). Within the context of immigrant entrepreneurship, components in this aspect primarily stem from governmental legislation, agreements, and standards that can encourage or discourage entrepreneurship activities in the host country (Mata \& Alves, 2018). For IEs, the formal aspects of institutions mainly govern their access to the host country's opportunities through two dimensions: the labour market and the entrepreneurial opportunity structure (Abd Hamid et al., 2019). It is documented that IEs usually face challenges in obtaining resources and experience administrative difficulties when starting their ventures, mainly stemming from their lack of knowledge in the host country's language and customs (Carter, Mwaura, Ram, Trehan, \& Jones, 2015). For instance, Somali IEs in the UK experience limitations in obtaining bank loans due to the banks' regulations (Ram, Theodorakopoulos, \& Jones, 2008), while Turkish IEs in the Netherlands engage in informal businesses due to barriers to formally registering their ventures (Kloosterman et al., 1999).

The informal aspects of institutions refer to values, norms and what is considered proper or preferred (DiMaggio \& Powell, 1983). Within the discussion in entrepreneurship, these aspects are represented by the entrepreneurs' knowledge and skills to conduct business within a specific country (Boudreaux, Nikolaev, \& Klein, 2019; Busenitz, Gomez, \& Spencer, 2000). For IEs, such aspects of institutions are influential through their knowledge of the host country's sociocultural environment. According to the Mixed Embeddedness Model and the Blocked Minority View in immigrant entrepreneurship, IEs equipped with knowledge of the host country's language and customs are likely to fare better than those who lack such knowledge, as these abilities enable them to access the host country's more profitable local market as opposed to the price-sensitive migrant segment (Cruz, Falcao, \& 
Barreto, 2018; Kloosterman et al., 1999). Some examples reflecting this issue include Korean IEs who operate their ventures in Korean-dense neighbourhoods in the US due to their limited knowledge in the host country's language and networks (Zonta, 2012) and Indian IEs who face difficulties in attracting the local Australian market due to unfamiliarity with the country (Azmat \& Fujimoto, 2016).

\section{Developing Non-Western Countries as Host Countries}

Developing non-Western countries or emerging markets offer IEs with a commercial environment shaped by state intervention and culture, which can be demonstrated in the management of their operations and marketing of their offerings (Barkema et al., 2015; Luo, 2016). With regards to the formal environment, developing non-Western countries are mainly characterised with fluid legal systems, and entrepreneurs navigate the systems through encouraging the financial, legal, and labour structures that mainly enable their entrepreneurial activities (Bruton, Ahlstrom, \& Obloj, 2008; Omri, 2020). For foreign entrepreneurs, these activities include forming and maintaining relationships with industry-relevant authorities and engage in nation-building activities (Jafari Sadeghi, Nkongolo-Bakenda, Anderson, \& Dana, 2019). This can be manifested in providing donations to charities supported by the industry in which they operate and engage in events initiated by relevant bodies in the host country. Here, entrepreneurs provide encouragement to the institutional environment which is relatively underdeveloped to support entrepreneurial activities in the host country.

With the increasing migration to non-Western countries comes an increase of interest in non-Western contexts for immigrant entrepreneurship. A research on IEs in Uzbekistan illustrates that the host country's characteristics as a transition economy provides entrepreneurs with comparatively less competitive environment for starting a business venture (Elo, 2016), a study on IEs in Belize and Cambodia suggest that such entrepreneurs begin to operate beyond the co-ethnic market as countries progress towards development (Verver, 2019), while a research on IEs in South Africa reveals that the entrepreneurs mainly navigate the host country environment through forming and maintaining relationships with disadvantaged and governing communities (Griffin-EL \& Olabisi, 2018). As such, IEs and their ventures in non-Western countries are mainly influenced by the host country's characteristics in terms of their development status and socio-economic environment. Malaysia as a host country provides a unique background for this study as its entrepreneurial institutions are largely designed to ensure the locals' competitiveness in business against foreign investors (Carney \& Andriesse, 2014). For example, foreign businesses are required to have a local business partner and hire local employees so as to ensure that the locals are not marginalised. In addition to the general challenges experienced by IEs in the host country - like the lack of acceptance of the local society and government bodies or difficulties in obtaining resources - the developing nation status and non-Western characteristics of Malaysia adds a layer of complexity for IEs, due to its protectionist stance towards locals inherent from its status as a developing nation, culture, and tradition-permeated environment based on its non-Western features.

\section{Research Focus}

There are two key takeaways from this section: (1) IEs in general face difficulties in accessing the local market as they lack host country knowledge, and (2) developing non-Western 
countries provide a more complex environment for decision-makers given the influence of the host country state intervention and culture. To address the research focus, a qualitative approach is undertaken to understand the phenomenon. Doing so will enable scholars to be more cognisant of the contextual roles of the host country in shaping IEs' experiences.

\section{Study Context}

Home countries selected in this study are Indonesia, Pakistan and Korea, with Malaysia as the host country. The qualitative approach employing multiple home countries provides this study with an insight on the similarities and differences of IEs' experiences in the host country, which can inform us on the way the host country environment influences entrepreneurial activities (Terjesen, Hessels, \& Li, 2016). As a multi-racial country, the business environment in Malaysia mainly aims for the development of its natives, reflected in the rules and regulations for business creation and expansion to ensure the competitiveness of locals against foreigners (Carney \& Andriesse, 2014). Furthermore, Malaysia's formal and informal profiles with regards to immigrant entrepreneurship may differ from that of conventional immigrant-receiving countries. Specifically, immigration to Malaysia is mainly composed of migrant workers, not IEs which lends to its unfamiliarity with IEs' businesses (Abd Hamid et al., 2019; Hugo, 2011). On the other hand, IEs' home countries in this study represent varying characteristics that influence IEs' journeys in their venture development (Brzozowski, Cucculelli, \& Surdej, 2014), in which Indonesian IEs can leverage from the similar Malay-based history, Pakistani IEs share similar Islamic values as Malaysia, while Korean IEs can benefit from their position as immigrants from a more prosperous country than the host country.

\section{MATERIAL AND METHODS}

This study employed a qualitative approach as such approaches are appropriate for questions about processes, understandings, and beliefs, involving making sense of the social world of the studied people (Taylor, Bogdan, \& DeVault, 2015; Wiseman, 1979). Primary sources of data include the IEs (focal primary source of data), embassy representatives, community leaders, and trade representatives of the three cases. A total of 40 respondents, including 32 IEs and eight supplementary interviewees, participated in the study, as shown in Table 1.

The primary data for this study was obtained through face-to-face, in-depth, and semi-structured interviews as part of a larger research on immigrant entrepreneurship in Malaysia. Interviews lasting 35-90 minutes were recorded on tape with the consent of interviewees. Prior to interviews, interviewees were contacted by phone and given details about the study. In total, 2800 minutes of face-to-face interviews were conducted during 40 interview sessions. Where necessary, further questions were asked to provide ongoing clarification (Miles \& Huberman, 1994). Secondary data sources were used for cross-checking purposes. During the phases of this research - which included outlining the framework, collecting data, analysing data, and subsequent iterations - the researcher employed a qualitative research software, NVivo for various purposes, including literature sorting, organising data sources, and coding. 
Table 1. Summary of respondents

\begin{tabular}{|l|l|l|l|}
\hline \multicolumn{1}{|c|}{ Case } & \multicolumn{1}{|c|}{ Primary source(s) } & \multicolumn{1}{c|}{ Pseudonyms } & \multicolumn{1}{c|}{ N } \\
\hline \multirow{4}{*}{ Indonesian IEs } & Entrepreneurs & El1-El10 & 10 \\
\cline { 2 - 4 } & Community leader & ICL & 1 \\
\cline { 2 - 4 } & Embassy representative & ITE & 1 \\
\cline { 2 - 4 } & Trade association representative & ITL & 1 \\
\hline \multirow{3}{*}{ Pakistani IEs } & Entrepreneurs & EP1-EP10 & 10 \\
\cline { 2 - 4 } & Community leader & PCL & 1 \\
\cline { 2 - 4 } & Embassy representative & PTE & 1 \\
\hline \multirow{3}{*}{ Korean IEs } & Entrepreneurs & EK1-EK12 & 12 \\
\cline { 2 - 4 } & Community leader & KCL & 1 \\
\cline { 2 - 4 } Additional source & Embassy representative & KTE & 1 \\
\hline \multirow{2}{*}{ Total } & Malaysian trade expert & MTE & 1 \\
\hline
\end{tabular}

Source: own study.

\section{RESULTS AND DISCUSSION}

\section{Case Summaries}

Indonesians form the largest pool of immigrants in Malaysia (United Nations, 2019), and within the context of this study, they are more represented in numbers relative to their Pakistani and Korean counterparts. The Islam-based affinity, racial and linguistic similarities, shared common history, and geographical proximity in the Malay Archipelago largely define bilateral Malaysian-Indonesian relations. These commonalities are assumed under the concept of ethnic-based kinship (Khalid \& Yacob, 2012), which encourages the sense of familiarity of Indonesians in Malaysia. In this study, the majority of the interviewees are first-generation male Indonesians in Malaysia, who came to Malaysia in 1998, and equipped with a minimum upper secondary education qualification. With regards to their motivations to pursue entrepreneurial ventures, nine of the interviewees responded that they saw a business opportunity while only one of them mentioned that it was due to difficulties in obtaining employment.

Pakistanis' South Asian links with Malaysian Indians and Islam-based affinity shared with Malaysia enable Pakistani migration to Malaysia through a sense of familiarity and brotherhood (Hugo, 2011). In this study, Pakistani IEs' clients are predominantly host country locals. Four of the interviewees came to Malaysia around 1989 until 1992, two of them arrived in Malaysia between 2006 and 2013 and the rest of them are second-generation Pakistanis in Malaysia. Nine of the interviewees responded that noticing a business opportunity was a motivation for them to start a business venture, while one of them stated that he came to Malaysia to continue a business venture.

For Korean IEs, Korean migration to Malaysia is largely attributed to various nationlevel policies and programs that welcoming immigrants from more developed countries. Such immigrants include businessmen, expatriates, and students. Most of Korean IEs in 
this study conduct restaurant and retail-based operations. The respondent pool for the case of Korean IEs is mainly composed of first-generation male Koreans with at least upper secondary education. In terms of their entrepreneurial motivations, eight respondents stated that it was based on opportunity, three mentioned that it was due to difficulties to find employment at home, and one responded that it was because he wanted to continue a business venture. Table 2 shows the details of this study's IE respondents.

Table 2. Details of primary interviewees

\begin{tabular}{|c|c|c|c|c|c|}
\hline Case & Interviewee & Gender & $\begin{array}{c}\text { Years } \\
\text { in Malaysia }\end{array}$ & Education & $\begin{array}{l}\text { Entrepreneurial } \\
\text { motivation }\end{array}$ \\
\hline \multirow{10}{*}{ 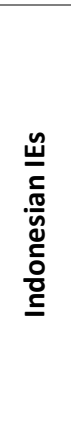 } & El1 & Male & $16-20$ & Master's Degree & Opportunity \\
\hline & $\mathrm{EI} 2$ & Male & $\geq 21$ & Upper secondary & Opportunity \\
\hline & EI3 & Male & $16-20$ & Master's Degree & Venture continuation \\
\hline & EI4 & Female & $6-10$ & Bachelor's Degree & Opportunity \\
\hline & EI5 & Female & $6-10$ & Master's Degree & Opportunity \\
\hline & EI6 & Male & $\geq 21$ & Upper secondary & Opportunity \\
\hline & EI7 & Male & $16-20$ & Bachelor's Degree & Opportunity \\
\hline & El8 & Female & $6-10$ & Bachelor's Degree & Opportunity \\
\hline & El9 & Male & $\geq 21$ & Upper secondary & $\begin{array}{c}\text { Lack of employment op- } \\
\text { portunities }\end{array}$ \\
\hline & El10 & Male & $\geq 21$ & Diploma & Opportunity \\
\hline \multirow{10}{*}{ 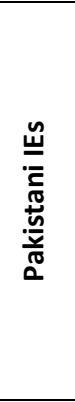 } & EP1 & Male & $\geq 21$ & Upper secondary & Opportunity \\
\hline & EP2 & Male & $0-5$ & Bachelor's Degree & Opportunity \\
\hline & EP3 & Male & $\geq 21$ & Bachelor's Degree & Venture continuation \\
\hline & EP4 & Male & $6-10$ & Bachelor's Degree & Opportunity \\
\hline & EP5 & Male & $\geq 21$ & Lower secondary & Opportunity \\
\hline & EP6 & Male & $\geq 21$ & Upper secondary & Opportunity \\
\hline & EP7 & Male & $\geq 21$ & Diploma & Opportunity \\
\hline & EP8 & Male & $\geq 21$ & Upper secondary & Opportunity \\
\hline & EP9 & Female & $\geq 21$ & Upper secondary & Opportunity \\
\hline & EP10 & Male & $\geq 21$ & Upper secondary & Opportunity \\
\hline \multirow{12}{*}{ 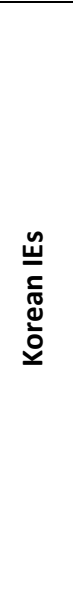 } & EK1 & Male & $0-5$ & Bachelor's degree & Opportunity \\
\hline & EK2 & Male & $0-5$ & Bachelor's degree & Opportunity \\
\hline & EK3 & Male & $0-5$ & Bachelor's degree & $\begin{array}{c}\begin{array}{c}\text { Lack of employment op- } \\
\text { portunities }\end{array} \\
\end{array}$ \\
\hline & EK4 & Male & $\geq 21$ & Bachelor's degree & $\begin{array}{c}\text { Lack of employment op- } \\
\text { portunities }\end{array}$ \\
\hline & EK5 & Male & $0-5$ & Bachelor's degree & Opportunity \\
\hline & EK6 & Male & $11-15$ & Bachelor's degree & Venture continuation \\
\hline & EK7 & Male & $6-10$ & Bachelor's degree & \begin{tabular}{|c|}
$\begin{array}{c}\text { Lack of employment op- } \\
\text { portunities }\end{array}$ \\
\end{tabular} \\
\hline & EK8 & Male & $\geq 21$ & Bachelor's degree & Opportunity \\
\hline & EK9 & Male & $11-15$ & Bachelor's degree & Opportunity \\
\hline & EK10 & Female & $16-20$ & Upper secondary & Opportunity \\
\hline & EK11 & Female & $6-10$ & Bachelor's Degree & Opportunity \\
\hline & EK12 & Male & $0-5$ & Bachelor's Degree & Opportunity \\
\hline
\end{tabular}

Source: own study. 
The migration characteristics of Indonesians, Pakistanis, and Koreans to Malaysia is illustrated in Table 3. As immigrant-sending countries, the migration profiles of different home countries offer a unique contextual setting (Vershinina, Barrett, \& Meyer, 2011); Indonesian immigrants may benefit from its large pool of immigrants and close historical links to Malaysia, Pakistani immigrants are able to leverage colonial links and Islam-based affinity, while Korean immigrants can utilise their relatively more prosperous position in the host country. As such, Indonesian, Pakistani, and Korean IEs in this study are equipped with home-country-specific characteristics that can be utilised in navigating the host country environment (Sundararajan \& Sundararajan, 2015).

Table 3. Statistics of Indonesians, Pakistanis, and Koreans migrating to Malaysia (source: United Nations, 2019)

\begin{tabular}{|c|c|c|c|}
\hline Year & Indonesia & Pakistan & Korea \\
\hline $\mathbf{1 9 9 0}$ & 252710 & 3208 & 1194 \\
\hline $\mathbf{1 9 9 5}$ & 421423 & 4484 & 1366 \\
\hline $\mathbf{2 0 0 0}$ & 726961 & 7140 & 1927 \\
\hline $\mathbf{2 0 0 5}$ & 863998 & 16632 & 2582 \\
\hline $\mathbf{2 0 1 0}$ & 960819 & 31814 & 3073 \\
\hline $\mathbf{2 0 1 5}$ & 1171677 & 80224 & 3747 \\
\hline $\mathbf{2 0 1 9}$ & 1225156 & 83884 & 3917 \\
\hline
\end{tabular}

Source: own study.

\section{Steps in Data Analysis}

Interview transcripts were developed into three main cases (Indonesian, Pakistani, and Korean IEs). For each cases, codes were extracted based on the main research question, which went through three stages of coding, shaped by the interviewees' quotations and then assembled into a data structure in the final two stages of analysis (Gioia, Corley, \& Hamilton, 2013). First, these codes were clustered into the groups of formal and informal barriers, as outlined by the institutional approach taken in this study, which produced 28 codes extracted from 75 quotations, which refer specifically to the challenges experienced in the host country. Codes relating to the host country's rules and regulations were organised in the "formal" cluster, while codes relating to culture and ways of implementation in business were organised in the "informal" cluster. The second stage of coding organises the codes into emerging themes upon application into the three cases. At this stage, a careful examination was re-employed to gauge the way the themes pose as challenges to the IEs. This step revealed that the challenges are mainly influential in shaping IEs' access to resources and opportunities. The final stage of coding categorises the themes into key dimensions influencing the challenges experienced by IEs and their ventures. This process revealed that the challenges experienced by IEs in a host country pertains to the following dimensions of the host country: (1) governing institutions, (2) resource-providing institutions, (3) society and (4) competition. This is described in Table 4. 
Table 4. Steps in data analysis

\begin{tabular}{|c|c|c|c|}
\hline & $\begin{array}{c}\text { Open codes based } \\
\text { on institutional dimensions }\end{array}$ & Emergent themes & $\begin{array}{l}\text { Aggregate } \\
\text { Dimension }\end{array}$ \\
\hline \multirow{16}{*}{ 乌ั } & Migrant business-related regulations & \multirow{4}{*}{$\begin{array}{l}\text { Regulative require- } \\
\text { ments for non-local } \\
\text { business start-up } \\
\text { processes }\end{array}$} & \multirow{9}{*}{$\begin{array}{l}\text { Governing in- } \\
\text { stitutions }\end{array}$} \\
\hline & Obtaining license & & \\
\hline & Rules regarding foreign workers & & \\
\hline & Special requirements for start-up for migrants & & \\
\hline & Official information issues & \multirow{2}{*}{$\begin{array}{l}\text { Facilities governing } \\
\text { information and } \\
\text { documentation }\end{array}$} & \\
\hline & Speed of documentation & & \\
\hline & Fake foreign worker agencies & \multirow{3}{*}{$\begin{array}{l}\text { Limited access to } \\
\text { potential employees } \\
\text { due to immigrant } \\
\text { ownership }\end{array}$} & \\
\hline & Industry-related regulations & & \\
\hline & Protective local unions & & \\
\hline & General funding regulations & \multirow{4}{*}{$\begin{array}{l}\text { Limited access to fi- } \\
\text { nancial capital due } \\
\text { to immigrant own- } \\
\text { ership }\end{array}$} & \multirow{7}{*}{$\begin{array}{l}\text { Resource- } \\
\text { providing in- } \\
\text { stitutions }\end{array}$} \\
\hline & Lack of support from larger corporations & & \\
\hline & Main client base limiting funding & & \\
\hline & Migrant status limiting funding & & \\
\hline & Complicated business mechanisms & \multirow{3}{*}{$\begin{array}{l}\text { Limited access to in- } \\
\text { formation due to } \\
\text { unfamiliarity }\end{array}$} & \\
\hline & Difficulties in getting information & & \\
\hline & Knowledge about institutional environment & & \\
\hline \multirow{10}{*}{$\begin{array}{l}\overline{0} \\
\stackrel{5}{0} \\
\stackrel{0}{\underline{s}}\end{array}$} & Attracting the local market & \multirow{4}{*}{$\begin{array}{l}\text { Understanding the } \\
\text { local market }\end{array}$} & \multirow{8}{*}{$\begin{array}{c}\text { Host country } \\
\text { society }\end{array}$} \\
\hline & Foreigner image & & \\
\hline & Hiring locals & & \\
\hline & Industry-related image & & \\
\hline & Language in business operation & \multirow{4}{*}{$\begin{array}{l}\text { Understanding the } \\
\text { host country's cul- } \\
\text { ture in business op- } \\
\text { eration }\end{array}$} & \\
\hline & Network diversity & & \\
\hline & Staff retention & & \\
\hline & Work styles & & \\
\hline & Competition & \multirow{2}{*}{\begin{tabular}{|l} 
Informal activities \\
within the host \\
country's migration \\
environment
\end{tabular}} & \multirow[b]{2}{*}{$\begin{array}{c}\text { Competition } \\
\text { in the host } \\
\text { country }\end{array}$} \\
\hline & Smuggling and counterfeiting & & \\
\hline
\end{tabular}

Source: own study.

\section{Key Dimension 1: Governing Institutions}

This dimension refers to the rules outlined by the regulative bodies in the host country with regards to starting a new venture. Codes in this dimension include issues on permits and special requirements for IEs' ventures as they are owned by non-citizens. The following quotations by EK10 (Korean food retailer), EP1 (carpet-focused entrepreneur), and a Pakistani trade expert (PTE) illustrate the way the host country's governing bodies influence IEs and their ventures: 
"I was working for the license for this business for four years. This is not a small operation; my business is quite profitable. I guess it is easier if it's another business like Korean restaurant businesses ... it is easier for them to get a license" (EK10).

"I applied for a wholesale permit, and it links with immigration because the nature of business operators. I got rejected a few times, as this company can be operated from overseas" (EP1).

"Among the challenges, one of them is to obtain a visa here. Expatriates and foreigners have to renew their visas every two years, the system is quite challenging as those who have stayed in Malaysia for 15 to 16 years must also do the same. Institution-wise, the performance of the immigration department can also be a challenge" (PTE).

Furthermore, the respondents explained that there were specific rules applied especially for non-citizens to begin entrepreneurial activities in the host country. In this regard IEs' activities are closely related with the limited opportunities inherent from their position as immigrants. This is clarified by the interviewed Indonesian and Pakistani trade experts (ITE and PTE respectively):

"To start a business, now ... I think it is more challenging. For legal workers, they have a limit as to how long they should be here. For businessmen, they have to adhere to local requirements, for example, a portion of their company must be owned by the locals" (ITE).

"It can be quite stressful for businessmen because of the regulations. Because business owners have to deal with the immigration department and business regulators, who provide them with licenses" (PTE).

\section{Key Dimension 2: Resource-Providing Institutions}

Codes that informed this dimension comprise of bodies pertaining to funding and employment, which includes local unions and foreign worker agencies. This dimension is related to the early stages of IEs' ventures, as they directly influence the start-up and survival of IEs' ventures in the host country. Such bodies generally limit IEs access to resources in relation to their status as non-citizens. As exemplified by Indonesian IEs, EI4 who runs a spa business and EI5 who is involved in food trading, obtaining funding from financial institutions such as banks and supporting agencies is challenging:

"The first two-and-a-half years were the hardest. I am a foreigner, so I was not allowed to borrow money from the bank. So whatever revenue I have received, I recycled back as capital" (EI4).

"The main challenge for me is funding. The banks in Malaysia are quite conservative" (EI5).

The respondents added that some organisations involved in the ecosystem of immigrant entrepreneurship in the host country mainly distorts the commencement of IEs' ventures. According to the data, there are two types of such organisations. The first type focuses on protecting locals of the host country - like an employee union - and the second 
type is more informal in nature, predominantly operated by illegal immigrant-based activities, such as informal foreign worker agencies. As IEs generally lack the local labour market information, they will mainly rely on a large number of foreign workers who are usually managed by informal foreign worker agencies. This quandary in employment is further exemplified by the following quotations by Indonesian IEs, EI3 (a trading entrepreneur) and $\mathrm{EI} 8$ (a restaurant operator):

"The union in Malaysia is also protective of employees, especially for employees who have been fired. Companies fire their workers for a reason ... they do not easily fire their workers they know .... For them, coming to work and leaving is just a game ... as if companies are the object of their games. About the union, although they do listen to all sides of the story, the inclination is still towards the employees" (EI3).

"Then, there is the problem of fake agents. Agents for manpower, I mean. These agents promise us workers, and they promise to handle all the legal matters involved ... but they just want money" (EI8).

\section{Key Dimension 3: Host Country's Society}

Items relating to this dimension are concerning IEs and their ventures within the context of the host country's society, which enables IEs' access to the more profitable local market during venture development. Codes informing this dimension pertain to attracting the host country's locals and language in their venture operations.

Attracting the local market is a challenge experienced by the IEs within this dimension. Specifically, adapting their offer to the host country is a challenge, as demonstrated by the following comments by EI1 (an herb entrepreneur), EI3 (a food trader), and EK12 (a restaurant operator). Here, marketing their products is difficult due to the non-local characteristics of their offerings and Els' knowledge about the local market:

"My challenge was to rebrand the image of herb-based products in Malaysia to be more local, so that people would not think of Indonesia when they see herbbased products" (EI1).

"Turns out that tailoring our marketing efforts was a challenge due to the cultural proximity. There are three main ethnicities in Malaysia, and they have different needs in terms of advertising. For instance, our media commercials have to be in Bahasa Malaysia and Mandarin, but also in English. Same goes for packaging .... In Indonesia, we only have to go through one language" (EI3).

"I suppose the challenge is to let people know about our products" (EK12).

Language is a challenge experienced by the IEs, and the following quotations by El8, who operates a restaurant business, and a Pakistani trade expert who link the challenges to difficulties in communicating with locals:

"For instance, Malaysians have their own slang even though we share similarities in language" (EI8).

“For newcomers, they are quite limited when it comes to language so they can't express themselves well" (PTE). 


\section{Key Dimension 4: Competition}

This dimension describes the competition around ventures owned and operated by IEs. Items such as competition with local and non-local businesses and smuggling and counterfeiting activities - which influences venture revenues - are important components of this dimension. This dimension is closely related with the development of IEs' ventures.

One of the main challenges within this dimension pertains to competition with locals and other IEs, as exemplified by the following quotations by EI9 who conducts a textile operation, EP7 who operates an ethnic food business, and confirmed by a Korean community leader $(\mathrm{KCL})$ :

"The increasing competition from locals, they are smart because they have the access to import from Vietnam and China, for the textile industry" (EI9).

"Competition is a challenge, for instance, one of my dishes has been copied by another Indian food restaurant" (EP7).

"Competition; among themselves, with other immigrant businesses, and most importantly, businesses owned by the Malaysian Chinese" (KCL).

Several Indonesian IEs explain that activities such as smuggling and counterfeiting by their competitors are their main challenges in conducting entrepreneurial activities in the host country. Further examination of the data suggests that this component is unique to the Indonesian IEs, as they link this challenge with Malaysian-Indonesian cultural similarities. The following comments by El3, El10, and an Indonesian trade association leader, ITL, illustrate that cultural similarities shared by Malaysia and Indonesia enables several unique challenges:

"Another challenge is having our products imitated. X [pseudonym] soy sauce is one of our products that we distribute. It came to our knowledge one day, from the complaints of our customers, that there is a line of soy sauce that has a similar packaging design as $X$ soy sauce, with a similar price. Unfortunately, this product is being imitated by a Malaysian company" (EI3).

"Because Indonesia and Malaysia are quite near, and the demand for jamu (traditional Malay-Indonesia herb) product is strong, there are people that travel between Malaysia and Indonesia, buy similar products like ours in Indonesia, and sell them cheap. Of course, they can sell these products cheap; they do not have to go through customs, shipping, labelling, licensing and all that, which creates cost" (El10).

"Indonesian businesses also face product and service imitation" (ITL).

Based on the narratives, IEs' challenges in the host country revolve around the host country's governing institutions, resource-providing institutions, local society, and competition environment. These dimensions interact within the host country's landscape of immigrant entrepreneurship in shaping IEs' access to resources and opportunities. The experiences of IEs revealed that although the host country is influential in shaping IEs' venture development in the host country, IEs' home countries offer a distinct contingency effect on 
how the ventures are conducted. The narratives indicate two unique instances for IEs according to their home countries. Firstly, funding is a challenge expressed by many of the IEs from Indonesia and Pakistan, but it was not mentioned by any of the Korean respondents. Secondly, Indonesian IEs expressed that the challenges are very much related to product and service imitation which can be linked to the cultural similarity of Malaysia and Indonesia. As such, we may observe that home-host country characteristics can offer distinct challenges for IEs in the host country. Nevertheless, as immigrants, IEs from Indonesia, Pakistan, and Korea experience similar challenges in the host country - from private and regulative institutions and from host country's society - with several components unique to the Indonesian IEs (challenges from host country competitors). This is summarised in Table 5 and subsequently discussed in the next section, which develops the findings of this study.

Table 5. Comparison of the cases in regard to the dimension of challenges

\begin{tabular}{|l|l|c|c|c|}
\hline \multirow{2}{*}{ Dimension/Case } & \multicolumn{1}{|c|}{ Main issues } & $\begin{array}{c}\text { Indonesian } \\
\text { IEs }\end{array}$ & Pakistani IEs & Korean IEs \\
\hline $\begin{array}{l}\text { Governing } \\
\text { institutions }\end{array}$ & Immigrant business regulations & $\checkmark$ & $\checkmark$ & $\checkmark$ \\
\cline { 2 - 5 } & Obtaining license & $\checkmark$ & $\checkmark$ & $\checkmark$ \\
\hline \multirow{2}{*}{$\begin{array}{l}\text { Resource-providing } \\
\text { institutions }\end{array}$} & Funding & $\checkmark$ & $\checkmark$ & $X$ \\
\cline { 2 - 5 } & Protective local unions & $\checkmark$ & $X$ & $X$ \\
\cline { 2 - 5 } & Fake worker agencies & $\checkmark$ & $X$ & $X$ \\
\hline \multirow{2}{*}{$\begin{array}{l}\text { Host country's } \\
\text { society }\end{array}$} & Attracting the local market & $\checkmark$ & $\checkmark$ & $\checkmark$ \\
\hline \multirow{3}{*}{ Competition } & Language in business operation & $\checkmark$ & $\checkmark$ & $\checkmark$ \\
\cline { 2 - 5 } & Competition with locals & $\checkmark$ & $\checkmark$ & $\checkmark$ \\
\cline { 2 - 5 } & Competition with non-locals & $\checkmark$ & $\checkmark$ & $\checkmark$ \\
\hline
\end{tabular}

Source: own study.

\section{Formal and Informal Institutional Nexus in Influencing Entrepreneurial Activities}

The host country can pose institutional barriers through formal "gatekeeping" rules and informal cultural expectations (DiMaggio \& Powell, 1991; Kostova, 1999). In the context of this study, the aforementioned institutional barriers are represented by special requirements for immigrant-based business owners and businesses to protect local entrepreneurs. This is inherent from the host country's position as a developing economy, whereby formal institutions play an important part in shaping the entrepreneurial ecosystem that affects new and foreign entrants in consideration of local firms (Busenitz et al., 2000). Based on the findings, the formal challenges experienced by IEs are more prominent in the early stages of venture development, through various requirements for immigrant business owners and attainment of licenses and permits. Those who are unable to satisfy such requirements may be left in the informal economy or rely on their co-nationals as a market, both of which are generally unprofitable. 
During the course of venture development, IEs find themselves navigating the informal aspects of the host country, especially in terms of attracting local consumers and competing within their selected industries. The informal institutional environment provides IEs with barriers with regards to understanding the more profitable local market (Wang \& Warn, 2018). Knowledge about the host country's local market and competition which are items that lie within the cognitive and normative realms of institutions are not likely to be available in a written format, unlike business license and permits. Here, commencing and expanding entrepreneurial ventures in the host country can be challenging, given the developing nature of the host country, and characteristics of IEs' home countries.

\section{Navigating a Host Country's Institutional Environment}

The institutional approach in entrepreneurship asserts that the host country is instrumental in encouraging or discouraging entrepreneurial activities in the host country. On the other hand, the literature on immigrant entrepreneurship shows that the host country's environment is generally discouraging for IEs. IEs' challenges in the host country are usually attributed to their lack of host country knowledge (including knowledge in language and networks) in interaction with the host country sociocultural context, which results in their reliance on marginal and informal sectors (Aliaga-Isla \& Rialp, 2013; Kloosterman et al., 1999).

Views on immigrant entrepreneurship have been heavily influenced by the IEs' experiences in developed Western countries (Aliaga-Isla \& Rialp, 2013), which can dent our understanding of immigrant-based enterprises, given the shift in migration towards non-Western countries. The complexity of Malaysia as a host country for foreigners (including IEs and expatriates) is mainly attributed to its developing nation status and nonWestern characteristics. Malaysia's developing nation status motivates the government to focus on the welfare of its local population, which translates into many business startup regulations and locals' acceptance of non-local offerings, while its non-Western characteristics are influential in the heavy emphasis on local language and customs. Through this study's findings, this research suggests that IEs' challenges within the host country span four key aspects, which are the governing institutions, resource-providing institutions, society, and competition in the host country. In reference to the experiences clarified by this study's main respondents, IEs from different home countries experience similar challenges in conducting business activities in the host country. However, as some components are unique to Indonesian IEs - such as products copied by local entrepreneurs and product smuggling - based on the narratives this research suspects that the extent of home country similarities to the host country could influence IEs' experiences in the host country. In this regard, in reference to the home-country-based experiences (Vershinina et al., 2011), this study proposes that a "one-size-fits-all" approach in regulating ventures owned and operated by IEs are not feasible in such countries. Such approach can offer sustainability for IEs and their ventures, but also for the regulating bodies of the host country. Figure 1 summarises the challenges experienced by IEs in the host country within the institutional lens. 


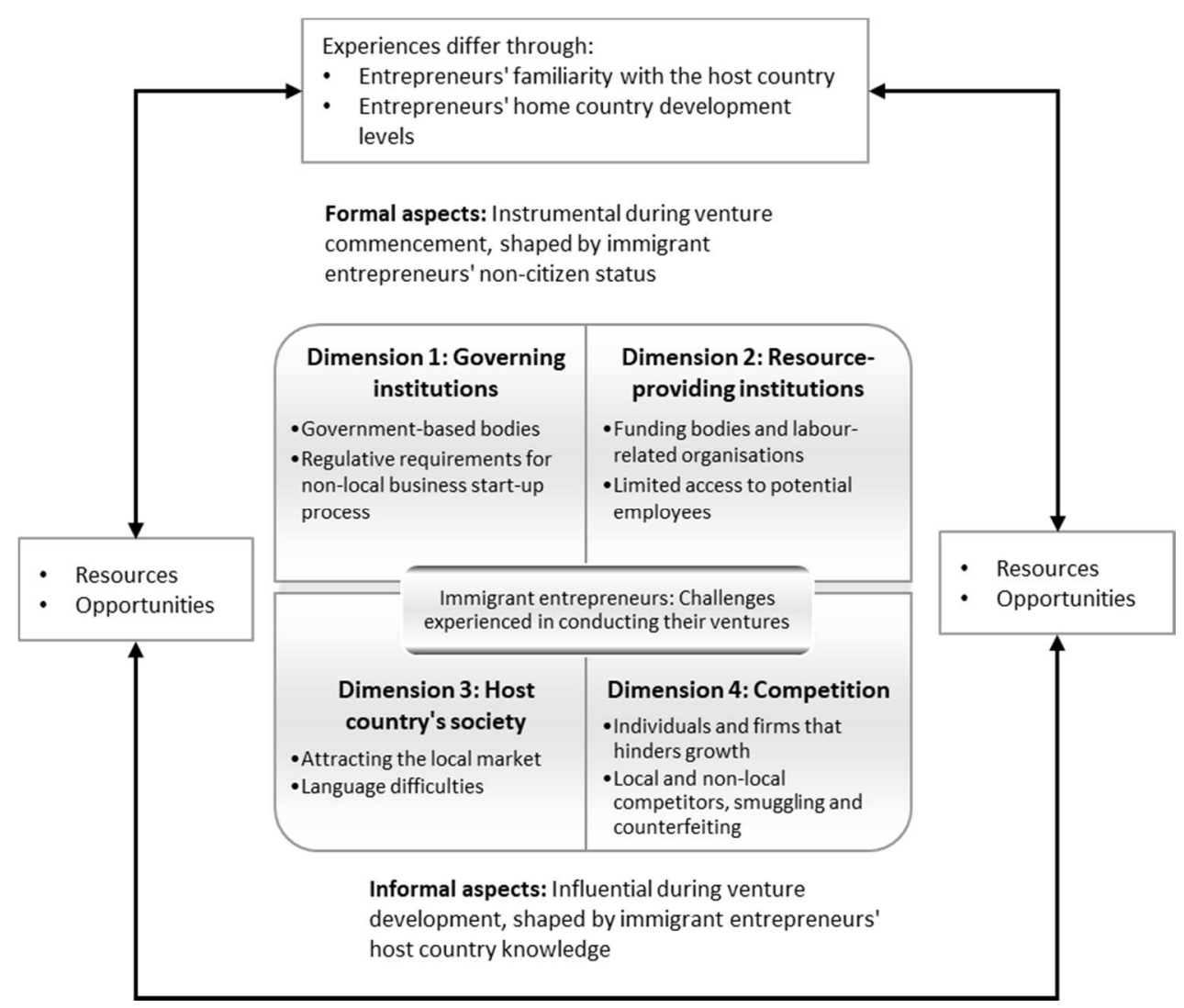

Figure 1. The proposed model of challenges experienced by immigrant entrepreneurs Source: own elaboration.

\section{CONCLUSIONS}

This article examined how institutions influence entrepreneurial activities conducted by IEs. The study was underpinned by North's $(1990,2005)$ institutional approach in clarifying that the host country influences entrepreneurial activities through formal and informal frameworks. As a research setting, this study focused on IEs from Indonesia, Pakistan, and Korea in the host country of Malaysia. Through a qualitative approach, the findings were organised into cases of Indonesian, Pakistan, and Korean IEs. This approach enabled contextualising with the use of entrepreneurs' narratives which facilitated a rich and in-depth examination of the phenomenon.

The findings show that the challenges experienced by IEs in the host country mainly stem from the governing institutions, resource-providing institutions, local society, and competition in the host country. These items co-relate with IEs' home countries and the host country's formal and informal frameworks in shaping IEs' access to resources and opportunities. Specifically, the host country's focus on ensuring local entrepreneurs' 
competitiveness against foreigners are manifested in various challenges on opportunities and resource provisions. The findings of this study produced a model of challenges experienced by IEs in a non-Western developing host country. This model can be instrumental to support the existing knowledge of immigrant entrepreneurship by illustrating how institutions in developing non-Western countries influence IEs and their ventures. As for policy and practice implications, based on this study, home country supporting bodies and host country policymakers are encouraged to engage and interact to build a more sustainable business landscape.

At the time when this article is written, developing non-Western countries host around five to ten percent of immigrants (United Nations, 2019), and it is expected that this number will keep rising. As such, it would be valuable for future research to examine immigrant entrepreneurship activities in countries within this category. Adopting a qualitative approach in a single host country is useful in studying this topic, yet there is much to understand about such contexts in immigrant entrepreneurship research. With regards to the limitations of the study, this paper encourages future research to examine this topic in different developing non-Western host countries to further strengthen the discussion around immigrant-based entrepreneurial activities.

\section{REFERENCES}

Abd Hamid, H., O'Kane, C., \& Everett, A. M. (2019). Conforming to the host country versus being distinct to our home countries: Ethnic migrant entrepreneurs' identity work in cross-cultural settings. International Journal of Entrepreneurial Behavior and Research, 25(5), 919-935. https://doi.org/10.1108/IJEBR-02-2018-0097

Aliaga-Isla, R., \& Rialp, A. (2013). Systematic review of immigrant entrepreneurship literature: Previous findings and ways forward. Entrepreneurship and Regional Development, 25(9-10), 819-844. https://doi.org/10.1080/08985626.2013.845694

Azmat, F., \& Fujimoto, Y. (2016). Family embeddedness and entrepreneurship experience: A study of Indian migrant women entrepreneurs in Australia. Entrepreneurship and Regional Development, 28(9-10), 630-656. https://doi.org/10.1080/08985626.2016.1208279

Barkema, H., Chen, X.-P., George, G., Luo, Y., \& Tsui, A. (2015). West meets East: New concepts and theories. Academy of Management Journal, 58(2), 460-479. https://doi.org/10.5465/amj.2015.4021

Boudreaux, C.J., Nikolaev, B.N., \& Klein, P. (2019). Socio-cognitive traits and entrepreneurship: The moderating role of economic institutions. Journal of Business Venturing, 34(1), 178-196. https://doi.org/10.1016/j.jbusvent.2018.08.003

Bruton, GD., Ahlstrom, D., \& Li, H.L. (2010). Institutional theory and entrepreneurship: Where are we now and where do we need to move in the future? Entrepreneurship Theory and Practice, 34(3), 421-440. https://doi.org/10.1111/j.1540-6520.2010.00390.x

Bruton, G.D., Ahlstrom, D., \& Obloj, K. (2008). Entrepreneurship in emerging economies: Where are we today and where should the research go in the future. Entrepreneurship Theory and Practice, 32(1), 1-14. https://doi.org/10.1111/j.1540-6520.2007.00213.x

Brzozowski, J., Cucculelli, M., \& Surdej, A. (2014). Transnational ties and performance of immigrant entrepreneurs: The role of home-country conditions. Entrepreneurship and Regional Development, 26(7-8), 546-573. https://doi.org/10.1080/08985626.2014.959068 
Busenitz, L.W., Gomez, C., \& Spencer, J.W. (2000). Country institutional profiles: Unlocking entrepreneurial phenomena. Academy of Management Journal, 43(5), 994-1003. https://doi.org/10.2307/1556423

Carney, M., \& Andriesse, E. (2014). Malaysia: Personal capitalism. In M.A. Witt \& G.S. Redding (Eds.), The Oxford Handbook of Asian Business Systems. Oxford, UK: Oxford University Press.

Carter, S., Mwaura, S., Ram, M., Trehan, K., \& Jones, T. (2015). Barriers to ethnic minority and women's enterprise: Existing evidence, policy tensions and unsettled questions. International Small Business Journal, 33(1), 49-69. https://doi.org/10.1177/0266242614556823

Chaganti, R.S., Watts, A.D., Chaganti, R., \& Zimmerman-Treichel, M. (2008). Ethnic-immigrants in founding teams: Effects on prospector strategy and performance in new Internet ventures. Journal of Business Venturing, 23(1), 113-139. https://doi.org/10.1016/j.jbusvent.2006.07.004

Cruz, E.P., Falcao, R.P. Q., \& Barreto, C.R. (2018). Exploring the evolution of ethnic entrepreneurship: The case of Brazilian immigrants in Florida. International Journal of Entrepreneurial Behavior and Research, 24(5), 971-993. https://doi.org/10.1108/IJEBR-08-2016-0239

Dheer, R.J.S. (2018). Entrepreneurship by mmigrants: A review of existing literature and directions for future research. International Entrepreneurship and Management Journal, 14(3), 555-614. https://doi.org/ 10.1007/s11365-018-0506-7

DiMaggio, P.J. (1991). Constructing an organizational field as a professional project: U.S. art museums 1920-1940. In W.W. Powell \& P.J. DiMaggio (Eds.), The New Institutionalism in Organizational Analysis (pp. 267-292). Chicago, IL: University of Chicago Press.

DiMaggio, P.J., \& Powell, W.W. (1983). The iron cage revisited - Institutional isomorphism and collective rationality in organizational fields. American Sociological Review, 48(2), 147-160.

DiMaggio, P.J., \& Powell, W.W. (1991). Introduction. In W.W. Powell \& P.J. DiMaggio (Eds.), The New Institutionalism in Organizational Analysis (pp. 1-38). Chicago, IL: University of Chicago Press.

Elo, M. (2016). Typology of diaspora entrepreneurship: Case studies in Uzbekistan. Journal of International Entrepreneurship, 14(1), 121-155. https://doi.org/10.1007/s10843-016-0177-9

Gioia, D.A., Corley, K.G., \& Hamilton, A.L. (2013). Seeking qualitative rigor in nductive research: Notes on the Gioia Methodology. Organizational Research Methods, 16(1), 15-31. https://doi.org/10.1177/1094428112452151

Greenman, A. (2013). Everyday entrepreneurial action and cultural embeddedness: An institutional logics perspective. Entrepreneurship and Regional Development, 25(7-8), 631-653. https://doi.org/10.1080/08985626.2013.829873

Griffin-EL, E.W., \& Olabisi, J. (2018). Breaking boundaries: Exploring the process of intersective market activity of immigrant entrepreneurship in the context of high economic inequality. Journal of Management Studies, 55(3), 457-485. https://doi.org/10.1111/joms.12327

Hugo, G. (2011). Migration and development in Malaysia: An emigration perspective. Asian Population Studies, 7(3), 219-241. https://doi.org/10.1080/17441730.2011.608983

Jafari Sadeghi, V., Nkongolo-Bakenda, J.-M., Anderson, R.B., \& Dana, L.-P. (2019). An institutionbased view of international entrepreneurship: A comparison of context-based and universal determinants in developing and economically advanced countries. International Business Review, 28(6), 101-117. https://doi.org/10.1016/j.ibusrev.2019.101588

Khalid, K.M., \& Yacob, S. (2012). Managing Malaysia-Indonesia relations in the context of democratization: The emergence of non-state actors. International Relations of the Asia-Pacific, 12(3), 355-387. https://doi.org/10.1093/irap/lcr024 
Kloosterman, R.C., van der Leun, J., \& Rath, J. (1999). Mixed embeddedness: (In)formal economic activities and immigrant businesses in the Netherlands. International Journal of Urban and Regional Research, 23(2), 252-266.

Kostova, T. (1999). Transnational transfer of strategic organizational practices: A contextual perspective. Academy of Management Review, 24(2), 308-324. https://doi.org/10.5465/AMR.1999.1893938

Lim, D.S.K., Oh, C.H., \& De Clercq, D. (2016). Engagement in entrepreneurship in emerging economies: Interactive effects of individual-level factors and institutional conditions. International Business Review, 25(4), 933-945. https://doi.org/10.1016/j.ibusrev.2015.12.001

Luo, Y. (2016). Competing in complex cross-cultural world: Philosophical insights from Yin-Yang. Cross Cultural and Strategic Management, 23(2). https://doi.org/10.1108/CCSM-01-2016-0020

Martinelli, A. (2004). The social and institutional context of entrepreneurship. In G. Corbetta, M. Huse, \& D. Ravasi (Eds.), Crossroads of entrepreneurship (pp. 58-74). New York, NY: Springer.

Mata, J., \& Alves, C. (2018). The survival of firms founded by immigrants: Institutional distance between home and host country, and experience in the host country. Strategic Management Journal, 39(11), 2965-2991. https://doi.org/10.1002/smj.2945

Miles, M.B., \& Huberman, M.A. (1994). Qualitative data analysis: An expanded sourcebook. Thousand Oaks, CA: SAGE.

North, D.C. (1990). Institutions, institutional change and economic performance. Cambridge, UK: Cambridge University Press.

North, D.C. (2005). Institutions and the process of economic change. Management International, 9(3), 1-7.

Omri, A. (2020). Formal versus informal entrepreneurship in emerging economies: The roles of governance and the financial sector. Journal of Business Research, 108, 277-290. https://doi.org/10.1016/j.jbusres.2019.11.027

Ram, M., Theodorakopoulos, N., \& Jones, T. (2008). Forms of capital, mixed embeddedness and Somali enterprise. Work, Employment and Society, 22(3), 427-446. https://doi.org/10.1177/0950017008093479

Sharma, P., Luk, S.T.K., Cardinali, S., \& Ogasavara, M.H. (2018). Challenges and opportunities for marketers in the emerging markets. Journal of Business Research, 86, 210-216. https://doi.org/10.1016/j.jbusres.2018.01.065

Sundararajan, M., \& Sundararajan, B. (2015). Immigrant capital and entrepreneurial opportunities. Entrepreneurial Business and Economics Review, 3(3), 29-50. https://doi.org/10.15678/EBER.2015.030303

Taylor, S.J., Bogdan, R., \& DeVault, M. (2015). Introduction to qualitative research methods: A guidebook and resource. Hoboken, New Jersey: Wiley.

Terjesen, S., Hessels, J., \& Li, D. (2016). Comparative international entrepreneurship: A review and research agenda. Journal of Management, 42(1), 299-344. https://doi.org/10.1177/0149206313486259

United Nations. (2019). Trends in international migrant stock: Migrants by destination and origin. from Department of Economic and Social Affairs https://www.un.org/en/development/desa/population/migration/data/estimates2/estimates19.asp

Vershinina, N., Barrett, R., \& Meyer, M. (2011). Forms of capital, intra-ethnic variation and Polish entrepreneurs in Leicester. Work, Employment and Society, 25(1), 101-117. https://doi.org/10.1177/0950017010389241 
Verver, M. (2019). Contextualising ethnic minority entrepreneurship beyond the west: Insights from Belize and Cambodia. International Journal of Entrepreneurial Behavior and Research, 25(5), 955-973. https://doi.org/10.1108/IJEBR-03-2019-0190

Wang, Y., \& Warn, J. (2018). Break-out strategies of Chinese immigrant entrepreneurs in Australia. International Journal of Entrepreneurial Behavior and Research (in press). https://doi.org/:10.1108/IJEBR-03-2017-0108

Wiseman, J.P. (1979). The research web. In J.M. Bynner \& K.M. Stribley (Eds.), Social research: Principles and procedures (pp. 113-121). New York, NY: Longman.

Zonta, M. (2012). The continuing significance of ethnic resources: Korean-owned banks in Los Angeles, New York and Washington DC. Journal of Ethnic and Migration Studies, 38(3), 463-484. https://doi.org/10.1080/1369183X.2012.658547

\section{Author}

\section{Hamizah Abd Hamid}

Senior lecturer at the National University of Malaysia (Universiti Kebangsaan Malaysia). Her PhD, which was obtained from University of Otago (New Zealand), dealt with issues of entrepreneurship within cross-cultural contexts. Her research interests include topics of cross-cultural entrepreneurship and international business.

Correspondence to: Dr. Hamizah Abd Hamid, Centre of Global Business and Digital Economy, Faculty of Economics and Business Management, National University of Malaysia, 43600 Bangi, Selangor, Malaysia, e-mail: hamizah.h@ukm.edu.my

ORCID (1) http://orcid.org/0000-0001-8031-8075

\section{Acknowledgements and Financial Disclosure}

I would like to express my gratitude to the participants involved in this research. There are no financial conflicts of interest to disclose.

\section{Copyright and License}

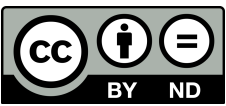

This article is published under the terms of the Creative Commons

Attribution - NoDerivs (CC BY-ND 4.0) License

http://creativecommons.org/licenses/by-nd/4.0/

Published by Cracow University of Economics - Krakow, Poland

The copyediting and proofreading of articles in English is financed in the framework and Higher Education of contract No. 913/P-DUN/2019 by the Ministry of Science and Higher Education 
